\title{
Management Economics in a Large Retail Company
}

\author{
W. Stanley Siebert \\ Birmingham Business School, University of Birmingham, Birmingham B15 2TT, United Kingdom, w.s.siebert@bham.ac.uk \\ Nikolay Zubanov \\ University of Tilburg, 5000 LE Tilburg, The Netherlands, n.v.zubanov@uvt.nl
}

\begin{abstract}
$\mathrm{W}$ e use unique data from 245 stores of a UK retailer to study links among middle (store) manager skills, sales, and manager pay. We find that, of the six management practice areas surveyed, the most important is "commercial awareness," where abler managers achieve up to $13.9 \%$ higher sales per worker. We find that many stores have poor managers on this indicator. However, the company is careful to incentivize managers, operating a scheme giving shares (approximately 20\%) in both positive and negative deviations of actual sales from expected. Abler managers do not receive higher pay, implying that their skills are company specific.
\end{abstract}

Key words: management; firm behavior; business economics; productivity; compensation methods History: Received July 20, 2009; accepted March 22, 2010, by Olav Sorenson, organizations. Published online in Articles in Advance July 2, 2010.

\section{Introduction}

Although debates continue on what makes good management, there is little doubt that management, just as other production inputs, matters to firm performance. Yet the observed effects of management on performance are in part shaped by corporate governance practices aimed at dealing with, among other issues, lack or misallocation of resources within the firm and agency concerns stemming from the division of ownership and control. This study combines the perspectives on management as an input into production function and as an outcome of corporate governance in an attempt to produce a fuller picture of its effect on performance.

Taking the management input perspective, we estimate the effect of middle management skills on the economic performance of the establishments of a single firm. Our unique, uniformly collected data from more than 200 retail stores of a UK clothing specialist offer an opportunity to study the important, but elusive, middle management input (Kanter 2004) in isolation from the confounding influences of most firm-specific factors. Controlling for a number of other inputs, observed and unobserved, we obtain plausible estimates of the differences in sales per worker between stores due to differences in their managers' skill grades, with the highest-grade managers achieving up to $13.9 \%$ higher sales per worker than those with the lowest grade.

We next turn to the corporate governance perspective, looking at the particular firmwide practices shaping the overall contribution of middle management to sales: manager allocation among stores and incentivization. We find that, because it is hard to dismiss underperforming managers or easily improve their allocation among stores, the company operates a type of incentive pay scheme in pay contracts reviewed every year. Under this scheme, store managers bear a definite share (approximately 20\%) in deviations of actual store sales from expected, giving them an incentive to perform to the best of their ability, high or low as the case may be. At the same time, we find that store managers' skill grades are not reflected in their pay. Consistent with the resourcebased view of the firm, these skills therefore exemplify highly specific human capital, valuable to the firm and yet not valued outside, and thus a source of competitive advantage for the firm that we study.

The rest of the article is organized as follows. Section 2 offers a review of the literature on the performance effects of middle management and how these managers are themselves managed. Section 3 introduces the data and estimation techniques used in the regression analysis that underlies the results presented in $\S \S 4$ and 5 . In $\S 6$ we use our regression results to assess the economic importance of management skills and corporate governance practices and relate our findings to the earlier studies. Section 7 concludes.

\section{Prior Literature and Our Study}

"Executives matter" argue Hambrick and Mason (1984, p. 194), but this proposition is surprisingly difficult to prove empirically. Further questions as to how much they matter, and how best to manage them, arise. Moreover, these questions radiate 
beyond the top executive to the top management team (Finkelstein et al. 2009, Chap. 5) and further to the ranks of middle managers below. The basic difficulty, of course, is that the management input is peculiarly difficult to measure.

Several methods are available. Historically, estimating the effect of management on performance began by capturing it through manager (or CEO) fixed effects. In other words, a panel of firms and CEOs was followed over time, allowing variation in performance to be apportioned into year, industry, company, and CEO effects. Studies within this approach started with Mundlak (1961) (see also Lieberson and O'Connor 1972, Lieberman et al. 1990, Bertrand and Shoar 2003, and Crossland and Hambrick 2007). Typically manager fixed effects are found to be statistically significant, though to many, starting with Lieberson and O'Connor (1972), they seem surprisingly small. There is also the question of what an "average" manager effect can mean, given that industries naturally vary in the extent to which "managerial discretion" (Finkelstein et al. 2009, pp. 26-36) can be exercised. A further problem is that the fixed effects are tracked via the CEO and offer little insight into Kanter's (2004) "innovative" middle management tier.

Another approach to capturing the management input is to analyze share price movements associated with CEO turnover, hypothetical or actually observed. Terviö (2008), using CEO pay as a proxy for their ability, calculates that, if we were to replace the CEOs of the 1,000 largest U.S. businesses with the lowest paid and presumably least able, their total capital value would fall by $0.13 \%-0.16 \%$ in 2004 , or by $4.3 \%-5.3 \%$ in the long run, applying a 3\% future discount rate (approximately the average of the Federal Reserve System's discount rate for 2004). Hayes and Schaefer (1999) find that share prices fall by 3\%-5\% when a (presumably more able) CEO quits for a better job, an effect of similar magnitude to Terviö's (2008). However, the applicability of the approach using share price movements is limited to large publicly quoted firms.

A more universal approach is to measure manager skills directly, which is what we do in this study. Well known examples of this approach, though initially confined to skills in the human resource management (HRM) area, are the Huselid (1995) and Ichniowski et al. (1997) management practice surveys. Other studies consider several HRM practices together, as separate inputs into production process (Capelli and Neumark 2001) or as "bundles" (Macduffie 1995, Ichniowski et al. 1997, Black and Lynch 2004). There are two general conclusions emerging from this literature: (i) HRM practices matter individually, and (ii) the effect is greater when they are bundled, making a coherent work system connected with other parts of the organizational capital of the firm.

More recently, the surveys have expanded to cover a wide range of management practices. Bloom and Van Reenen's's (2007) study scores eighteen individual practices from 732 firms in four countries (the United Kingdom, the United States, France, and Germany) to produce an average management score for each company. This score, reflecting the overall ability of the top management team, is found to be positively associated with a range of firm economic performance measures. Griffiths et al. (2006) use the "balanced scorecard" approach of Kaplan and Norton (1992) to calculate manager scores on financial, customer satisfaction, innovation, and internal controls criteria in stores of a UK building materials wholesaler, again finding a strong association with firm performance. Their study is more like ours in that it looks at the middle manager level, with the company's top management policies given.

The contribution of managers to firm performance is affected by what is known as the "agency problem"-a misalignment of the manager's and the owner's incentives (Bebchuk and Fried 2003, Carpenter and Wade 2002). This problem is particularly important for large and geographically dispersed firms such as our study company-hence the importance of managing the managers in our study. Specifically, we consider two practices of managing the managers applied within our study company: incentivizing store managers to perform and allocating managers suitably across stores within the firm.

There are two main theoretical models of incentive pay: Holmström's's (1979) pay-for-performance model, which predicts that conditioning pay on output is essential for inducing worker effort, and Lazear and Rosen's (1981) tournament-based model, which predicts that effort is induced by workers' competing for higher positions in an organizational hierarchy offering progressively higher pay. Substantial empirical evidence exists on both models (see Prendergast 1999 for a survey). Specifically for the middle management level, Lambert et al. (1993) find that the earnings gap between the plant manager and the corporate $\mathrm{CEO}$ can be explained through a mix of pay for performance and tournaments-based elements. Roth and O'Donnell's (1996) study of manager pay in overseas subsidiaries finds that the weight given to pay for performance increases with "cultural distance" of a subsidiary manager from central headquarters, which is plausible because cultural distance increases information asymmetry and hence the extent of the agency problem. As a contribution to the pay-forperformance literature, we show how our study company has developed a manager pay review system based on expected annual store sales to make the 
most of its available store manager pool. Building on this system, we develop a measure of expected sales and find that positive (negative) deviations are rewarded (punished), as expected.

As for manager allocation, Lucas's (1978) model predicts that abler managers will end up in control of larger establishments, because of the "scale of operations" effect (that is, the contribution of good managers to overall profit is magnified by their establishment's size). We find the scale of operations effect is indeed manifested among the company's stores, but it seems weaker than in the larger economy (as in Terviö 2008). Store managers appear difficult to reallocate perhaps because their skills are highly specific (such skills being difficult to imitate and hence a source of competitive advantage-see Holcomb et al. 2009). In other words, middle managers' skills in our company exemplify skills specifically tied (Bailey and Helfat 2003) to knowledge of their particular store and its personnel, customers, and internal strengths and weaknesses. The high proportion of top managers (nearly 90\% in Bailey and Helfat's 2003 study) recruited internally already suggests skill specificity at the top level. We now find such specificity farther down the hierarchy as well.

\section{Data and Method}

\subsection{The Study Company}

Our study company is a large UK-based clothing retailer with more than 600 stores in the United Kingdom and many more internationally, though we confine ourselves to the UK operations. At the top of the organizational hierarchy is central headquarters (HQ), where companywide financial, marketing, and operational decisions are made. Thus, HQ decides on the goods to be sold and managers to be employed at each store, as well as their remuneration. Sales assistants' pay rates and store wage budgets are also set by HQ in the beginning of each accounting year (February), taking into account changes in operating environment and newly acquired information. Wage budgets, in particular, are set according to a "wage budget rule," allowing wages to be no more than a certain fraction (approximately 10\%) of the previous year's sales. This rule of course sets an important constraint on how many worker-hours a manager can hire over the year because wage rates are given. A network of twenty regional managers coordinates store managers and, importantly, negotiates the implementation of the wage budget rule and helps assess store manager performance.

Even though store managers' activities are closely directed by $\mathrm{HQ}$, which sets both product prices and wage budgets, they have considerable autonomy in the day-to-day running of their stores, and their assessments reveal considerable variation in their skill levels (see §3.3). Generally speaking, they must maintain an attractive store appearance and provide adequate customer service within the store's wage budget. An important part of this task is ensuring there are enough sales assistants at all times, which is generally achieved through maintaining a pool of part-time workers employed at peak times and laid off when business is quiet. Store managers are also responsible for sales assistants' selection, training, and promotion; in fact, nearly two-thirds of store managers are recruited from sales assistants.

Our analysis runs through the data collected for the trading year February 2005 to February 2006. The reason for taking only one year's worth of observations is to ensure that the same manager was in charge of a given store for the entire study period. All managers who participated in the assessment must have been running their stores for at least a year as of February 2006. There are 245 such stores.

\subsection{Descriptive Statistics}

Table 1 offers an illustration of the workings of our study company and its environment. The average store is, in UK terms, comparable to a small enterprise, producing approximately $£ 60$ worth of sales per worker-hour, employing 314.5 worker-hours of labor per week (8.4 full-time-equivalent (FTE) workers, 1 week $=37.5$ hours), and occupying approximately 150 square meters of space (store space being our measure of capital input). Even though all our stores belong to the same company, selling the main brand of medium-priced casual clothing and generally located in large shopping centers, they vary considerably in sales per worker-hour (our measure of labor productivity), giving a standard deviation of $£ 15.07$. We aim to explain this high variation in productivity.

The company needs to accommodate large fluctuations in business by day of the week and season, which requires a flexible workforce. Indeed, most of the sales assistants work less than 15 hours per week. There is also considerable employee turnover (the FTE separation rate is $15 \%$ annually, approximately $30 \%$ in headcount terms), characteristic of the retail sector. Such fluid conditions present a challenge to the store manager, who must match labor input to fluctuating demand while keeping labor turnover under control. Competitive pressures, averaging 36.45 stores in the catchment area, pose another challenge for store managers.

We see that an average store manager is in her late 30s and has been with the company for a considerable part of her working life. Most of the managers are women, but the share of men (0.27) is twice as high as for sales assistants. Their average pay rate 
Table 1

Descriptive Statistics

\begin{tabular}{|c|c|c|c|}
\hline Variable & Obs. & Mean & Std. dev. \\
\hline \multicolumn{4}{|c|}{ Store characteristics } \\
\hline Sales per hour worked & 12,671 & 59.93 & 15.07 \\
\hline Total hours worked per week & 12,671 & 314.48 & 211.76 \\
\hline $\begin{array}{l}\text { Capital control: Store space in } \\
\text { square meters }\end{array}$ & 245 & 148.98 & 82.47 \\
\hline \multicolumn{4}{|l|}{ Store belongs to: } \\
\hline Main brand & 245 & 0.93 & 0.26 \\
\hline Other brands & 245 & 0.07 & 0.26 \\
\hline \multicolumn{4}{|l|}{ Store location: } \\
\hline Stand-alone, city center & 245 & 0.13 & 0.34 \\
\hline Stand-alone, local area & 245 & 0.1 & 0.3 \\
\hline Subregional shopping center & 245 & 0.44 & 0.5 \\
\hline Regional shopping center & 245 & 0.16 & 0.37 \\
\hline Other & 245 & 0.17 & 0.36 \\
\hline $\begin{array}{l}\text { Share of children's products in } \\
\text { total sales }\end{array}$ & 245 & 0.29 & 0.11 \\
\hline \multicolumn{4}{|c|}{ Sales assistants characteristics } \\
\hline $\begin{array}{l}\text { Average sales assistant's age, } \\
\text { years, adjusted for full-time } \\
\text { equivalence (FTE) }\end{array}$ & 245 & 34.71 & 6.61 \\
\hline $\begin{array}{l}\text { Average sales assistant's tenure, } \\
\text { years, FTE }\end{array}$ & 245 & 7.26 & 3.71 \\
\hline $\begin{array}{l}\text { Share of male sales assistants, } \\
\text { FTE }\end{array}$ & 245 & 0.13 & 0.14 \\
\hline \multicolumn{4}{|l|}{ Share of sales assistants working: } \\
\hline 0-4 hours per week & 245 & 0.33 & 0.19 \\
\hline 5-14 hours per week & 245 & 0.25 & 0.17 \\
\hline 15-30 hours per week & 245 & 0.22 & 0.16 \\
\hline $30+$ hours per week & 245 & 0.2 & 0.1 \\
\hline $\begin{array}{l}\text { Sales assistant's average hourly } \\
\text { pay }\end{array}$ & 245 & 5.02 & 0.23 \\
\hline $\begin{array}{l}\text { Area average hourly pay for a } \\
\text { similar job }^{\mathrm{a}}\end{array}$ & 21 & 7.49 & 0.87 \\
\hline $\begin{array}{l}\text { Number of sales assistants } \\
\text { working on an average week }\end{array}$ & 12,656 & 15.32 & 11.06 \\
\hline $\begin{array}{l}\text { Number of sales assistants ever } \\
\text { worked during the year }\end{array}$ & 245 & 22.47 & 17.04 \\
\hline Separations rate, FTE & 245 & 0.15 & 0.11 \\
\hline \multicolumn{4}{|c|}{ Area characteristics } \\
\hline Area average pay & 21 & 11.05 & 1.54 \\
\hline Area unemployment rate & 21 & 0.05 & 0.01 \\
\hline $\begin{array}{l}\text { Number of competitors in a } \\
\text { store's catchment area }{ }^{c}\end{array}$ & 245 & 36.45 & 25.89 \\
\hline \multicolumn{4}{|c|}{ Store manager characteristics } \\
\hline Manager age (years) & 236 & 38.06 & 10.09 \\
\hline Manager experience (years) & 236 & 10.71 & 6.38 \\
\hline Store manager is male & 236 & 0.27 & 0.44 \\
\hline $\begin{array}{l}\text { Manager hourly pay (based on } \\
1,900 \text { hours worked per year), } \\
\text { data for } 2006\end{array}$ & 236 & 11.24 & 2.59 \\
\hline $\begin{array}{l}\text { Area average hourly pay for a } \\
\text { similar job }{ }^{\mathrm{b}} \text {, data for } \\
\text { January-September } 2006\end{array}$ & 21 & 11.06 & 1.45 \\
\hline
\end{tabular}

antermediate, routine, and semiroutine sales and services (categories 7.2, 12.1, 12.2, and 13.1 of the Labour Force Survey occupation classifier).

'Lower managerial (category 5.0) and lower and higher supervisory occupations (categories 6.0 and 10.0).

'Information on competitors in each store's catchment area is derived from a company survey.
(£11.24 per hour) exceeds that for similar occupations in the area ( $£ 11.06$ per hour)—unlike that of sales assistants. Note that the manager pay data are for 2006, one year after the sales data, as our incentive pay model (\$5.1) requires.

\subsection{Key Behavioral Indicators}

The basis for our study is the company's unique survey of six management practice areas, or key behavioral indicators (KBIs): "sales focus," "commercial awareness," "developing people," "drive and personal development," "leadership," and "planning and organizing." Each participating store manager received one of the three grades for each KBI- "development need" (signifying inadequate performance), "capable" (minimum appropriate performance), and "strength" (exceptional performance)-matching the grade descriptions in Table 2. In addition to the individual KBI grades, the managers' overall performance was also graded, ranging from $\mathrm{E}$ (lowest) to A (highest), based on the sum of scores on individual KBIs. All managers who had worked in their stores for at least one year as of early 2006 took part. This minimum tenure restriction ensures that every store manager had enough evidence for his or her skills to be adequately assessed. It took a dedicated HR team, store, and area managers five months to collect, verify, and summarize these data.

The objectivity of the KBI grades is important because we wish to use them to help explain store performance (as, indeed, does the company). Let us first consider the KBI measurement method. Each store manager had initially to self-assess by filling in the survey questionnaire. Those self-assessments were later discussed with the area managers, and then, based on the evidence supporting the self-assessment results, agreed assessments were produced.

As we show, it is the area manager who gives the KBI measures objectivity. The question is whether the area manager is influenced by store sales themselves in assessing the store manager skills, which we now consider. Given the lack of repeated KBI observations by store, we cannot test for a possible reverse causality between sales and KBI grades, which remains a caveat to our analysis. However, we believe that sales affecting KBI grades is unlikely, because there is no mention of sales in the KBI grade descriptions. Sales together with other "hard" performance outcomes, such as employee turnover and the wage budget target, were monitored in a separate Key Performance Indicators survey administered by another department within the company. The KBI survey, on the other hand, is an expensive effort aimed at identifying managers' strengths and weaknesses and testing the company's beliefs about which managerial skills are good for performance (in fact, our results do not support some of these beliefs). 
Table 2

Key Behavioral Indicators

$\mathrm{KBI}$ and components standards

2. Uses company initiatives to increase sales

3. Exhibits and develops selling skills within the team

4. Uses reports and information to improve sales performance

5. Uses knowledge of fashion trends to enhance sales performance

1. Aligns own plans to business priorities

2. Uses knowledge of products to maximize business performance

3. Delivers controllable costs

4. Observes own and monitors competitors' activity

1. Is a positive role model

2. Is an effective communicator

3. Builds winning teams

4. Makes sound decisions

5. Manages poor performance

6. Deals with and resolves problems

7. Manages change

1. Uses company recruitment and induction practices

2. Uses training to continuously improve performance

3. Uses feedback to improve performance

4. Completes performance development reviews

5. Develops people for the future

Grade capable

Grade strength

\section{Sales focus}

Delivers the company operational and visual standards to drive sales performance

Makes sure all training and selling initiatives are delivered

Displays thorough product knowledge and effective selling skills; flexes selling conversations according to consumer types

Reviews and analyzes reports and sales information to improve performance

Keeps up to date with fashion trends, can relate them to products, and uses this knowledge in selling

\section{Commercial awareness}

Makes plans for peak trading periods to ensure effective use of resources

Knows the performance of all departments and key products within each of these

Can manage payroll and makes plans to deliver wage control

Constantly reviews the store through the eyes of a customer and makes adjustments to improve the shopping experience

\section{Leadership}

Behavior and work of a high professional standard. Respected by colleagues

Sets clear expectations of performance standards Communicates information clearly and concisely

Encourages a sense of friendly competition and cooperation; praises and recognizes good performance

Can be relied on to make decisions right for the store and the business

Takes appropriate and timely action to address poor performance

Can deal with problems and seeks advice when needed to resolve them

Reacts to change positively and sells the benefits to the team

\section{Developing people}

Follows company procedures in recruitment; provides induction training to new hires

Ensures everyone complete standard training requirements; keeps training records up to date

Gives genuine praise and constructive criticism to improve performance

Ensures all employees attend one review meeting each year to agree on business goals and identify development opportunities

Identifies and develops individuals who demonstrate potential and a desire to progress
Generates a passion for high operational and visual standards in everyone; store consistently delivers high standards

Gains commitment from all team members so that training and selling initiatives become properly embedded

Can model excellent selling skills; observes performance on sales floor and gives feedback and recommendations for improvement

Uses information to identify additional selling opportunities

Develops in others a knowledge of fashion trends and an ability to incorporate this when selling

Knows the trading period strategy and uses it to identify priorities and determine plans that will provide the best financial results

Makes the best use of space on the sales floor given the store's product mix

Is flexible and can adjust manpower to deliver a great experience for customers while achieving the wage control targets

Monitors local competitors and considers shopping experiences in other retailers to make improvements in own store

Is a highly credible role model, an inspiration for others

Listens and responds well. Encourages sharing of ideas; adapts the style of communication to build rapport

Generates a positive "buzz"; coaches and motivates the team to succeed while maintaining good working relationships

Makes excellent decisions and considers their immediate and long-term impact; puts plans in place to overcome potential barriers

Differentiates between conduct and capability, identifies the root cause of poor performance and manages it accordingly

Tackles problems in their early stages and can make sound decisions to resolve them objectively

Puts plans in place to implement change successfully; deals with resistance in a positive way

Has a good working knowledge of recruitment practices; follows up all induction sessions to ensure their effectiveness

Identifies training need and uses available materials to deliver effective training

Consistently uses feedback to enhance performance

Follows up the formal performance review with informal reviews of the agreed goals and development activities

Has a succession plan in place and develops talent so that positions can be filled internally 
Table 2

(Continued)

$\mathrm{KBI}$ and components

Grade capable

Grade strength

1. Is committed to company standards

2. Is motivated to succeed

3. Responds to challenges positively

4. Takes responsibility for own development

1. Plans in advance

2. Prioritizes tasks

3. Delegates effectively and meets deadlines
V. Drive and personal development

Shows commitment to achieve agreed performance standards

Demonstrates passion and enthusiasm, is motivated to succeed

Maintains a positive outlook and responds to challenges well

Maintains a personal development plan; can demonstrate improvements in skills, knowledge, and behavior over time VI. Planning and organizing

Uses company materials to plan in advance

Considers tasks according to importance and urgency; understands the difference among "must do," "should do," and "nice to do"

Delegates tasks and follows them up to ensure that deadlines are met
Strives to exceed performance standards

Is a self-starter, is consistently passionate, and shows dedication to the task

Demonstrates a "can do" attitude. Is resilient under challenging circumstances

Looks for opportunities to enhance skills and knowledge; shows initiative to improve self

Plans ahead on a daily and weekly basis and carefully considers forthcoming trading periods

Prioritizes logically and according to maximum business benefit

Delegates appropriately and takes time to put tasks into context; monitors progress so that deadlines are met

Note. Grade "development need" was given for substandard performance.

Source. Survey documentation, minimal editing applied.

Looking at the KBI grade descriptions in Table 2, we see an extensive range of practices, from the more administrative (such as planning and organizing) to the more entrepreneurial (such as commercial awareness). Attention is paid to HRM practices, too, with the KBI developing people related to some of the "high-performance" work practices described in Pfeffer (1998), such as training and communication with employees. Admittedly, there are overlaps; for example, both sales focus and leadership reward team building. At the same time, the important commercial awareness KBI appears to be unique. It emphasizes four skills: Knowing the trading period strategy, monitoring local competition, adjusting manpower subject to wage control, and making best use of space-none of which are touched on by the other KBIs. As we show below, by comparing the estimates for the KBIs entered separately and jointly into the sales equation, the characteristics of commercial awareness matter for sales the most. To repeat, none of the four skills measured under this KBI mentions store sales.

Table 3 shows that the performance of store managers with respect to the KBIs varies considerably. Approximately $20 \%$ were rated as development need for sales focus, commercial awareness, leadership, and drive and personal development, and approximately one-quarter were rated at the highest grade. The best-performing KBI is planning and organizing, in which $95 \%$ of the store managers achieve satisfactory performance. The weakest results are for developing people, with $40 \%$ of store managers rated as underperforming.
We would expect the KBI grades to be linked to store labor productivity. Indeed, as Table 3 demonstrates, managers with higher KBI grades are found in more productive stores. This early indication of the link between manager skills and performance is encouraging but needs to be tested controlling for other factors, especially the fact that stores with higher-graded managers are also larger and located in more competitive areas, each of these factors affecting productivity on its own. In the sections to follow, we apply multivariate regression analysis to test whether the KBIs really translate into sales performance.

\subsection{Estimation Issues}

We begin our regression analysis by estimating the contribution of manager skills to sales, controlling for labor and store space, as well as store, area, and workforce characteristics. We do not have data on the cost of sales, which is an obvious input in the sales function, but, plausibly assuming that it is a constant fraction of the total sales, we can abstract from it. We assume that the sales function is Cobb-Douglas. Our robustness checks (skipped here but available on request) show that this simple functional form is adequate for our data.

Because management input is fixed for the whole year, we could in principle aggregate our weekly sales and labor input data and estimate the sales function on the year totals. The problem with this simple approach, however, is that it may bias the estimate for the elasticity of sales with respect to the labor input, leading to biased estimates for manager skills because labor and management inputs are correlated. 
Table 3 Averages of Key Variables by KBI Grade

\begin{tabular}{|c|c|c|c|c|c|c|c|}
\hline $\mathrm{KBI}$ & Grade & $\%$ & $\begin{array}{c}\text { FTE } \\
\text { personnel }\end{array}$ & $\begin{array}{c}\text { Store } \\
\text { space, sq. m }\end{array}$ & $\begin{array}{l}\text { Manager } \\
\text { pay, £/hour }\end{array}$ & $\begin{array}{l}\text { Competition, } \\
1 \text { to } 4^{\mathrm{a}}\end{array}$ & $\begin{array}{c}\text { Sales per } \\
\text { hour worked, } £\end{array}$ \\
\hline Sales focus & $\begin{array}{l}\text { Development need } \\
\text { Capable } \\
\text { Strength }\end{array}$ & $\begin{array}{l}17.14 \\
59.18 \\
23.68\end{array}$ & $\begin{array}{r}6.49 \\
7.97 \\
11.61\end{array}$ & $\begin{array}{l}119.57 \\
142.93 \\
185.37\end{array}$ & $\begin{array}{l}10.48 \\
10.95 \\
12.55\end{array}$ & $\begin{array}{l}2.24 \\
2.41 \\
2.82\end{array}$ & $\begin{array}{l}55.45 \\
59.47 \\
61.60\end{array}$ \\
\hline Commercial awareness & $\begin{array}{l}\text { Development need } \\
\text { Capable } \\
\text { Strength }\end{array}$ & $\begin{array}{l}17.55 \\
56.33 \\
26.12\end{array}$ & $\begin{array}{r}6.56 \\
7.75 \\
11.72\end{array}$ & $\begin{array}{l}125.73 \\
139.41 \\
185.24\end{array}$ & $\begin{array}{l}10.29 \\
10.96 \\
12.54\end{array}$ & $\begin{array}{l}2.19 \\
2.31 \\
3.07\end{array}$ & $\begin{array}{l}55.59 \\
58.49 \\
62.80\end{array}$ \\
\hline Leadership & $\begin{array}{l}\text { Development need } \\
\text { Capable } \\
\text { Strength }\end{array}$ & $\begin{array}{l}17.55 \\
54.29 \\
28.16\end{array}$ & $\begin{array}{r}7.30 \\
7.49 \\
11.48\end{array}$ & $\begin{array}{l}136.25 \\
132.71 \\
188.28\end{array}$ & $\begin{array}{l}10.55 \\
10.83 \\
12.53\end{array}$ & $\begin{array}{l}2.40 \\
2.27 \\
2.86\end{array}$ & $\begin{array}{l}57.34 \\
59.24 \\
61.01\end{array}$ \\
\hline Developing people & $\begin{array}{l}\text { Development need } \\
\text { Capable } \\
\text { Strength }\end{array}$ & $\begin{array}{l}39.59 \\
44.90 \\
15.51\end{array}$ & $\begin{array}{r}7.33 \\
8.24 \\
12.74\end{array}$ & $\begin{array}{l}134.50 \\
140.66 \\
210.02\end{array}$ & $\begin{array}{l}10.65 \\
11.08 \\
13.24\end{array}$ & $\begin{array}{l}2.31 \\
2.39 \\
3.09\end{array}$ & $\begin{array}{l}58.32 \\
59.36 \\
62.20\end{array}$ \\
\hline $\begin{array}{c}\text { Drive and personal } \\
\text { development }\end{array}$ & $\begin{array}{l}\text { Development need } \\
\text { Capable } \\
\text { Strength }\end{array}$ & $\begin{array}{l}21.22 \\
49.80 \\
28.98\end{array}$ & $\begin{array}{r}6.87 \\
8.00 \\
10.83\end{array}$ & $\begin{array}{l}125.04 \\
140.58 \\
180.95\end{array}$ & $\begin{array}{l}10.61 \\
11.10 \\
11.95\end{array}$ & $\begin{array}{l}2.29 \\
2.35 \\
2.80\end{array}$ & $\begin{array}{l}57.20 \\
59.43 \\
61.04\end{array}$ \\
\hline Planning and organizing & $\begin{array}{l}\text { Development need } \\
\text { Capable } \\
\text { Strength }\end{array}$ & $\begin{array}{r}4.49 \\
42.04 \\
53.47\end{array}$ & $\begin{array}{l}7.13 \\
6.97 \\
9.97\end{array}$ & $\begin{array}{l}135.22 \\
124.62 \\
169.29\end{array}$ & $\begin{array}{l}11.02 \\
10.54 \\
11.80\end{array}$ & $\begin{array}{l}2.36 \\
2.18 \\
2.71\end{array}$ & $\begin{array}{l}60.56 \\
57.53 \\
60.86\end{array}$ \\
\hline
\end{tabular}

${ }^{\mathrm{a}} 1=$ number of competitors $1-17$ (bottom 25\%), $2=18-30,3=31-51$, and $4=52+$ (top $25 \%$ ).

The current year's labor input is correlated with the last year's shock to sales through the wage budget rule. If the last year's shock to sales continues to affect the current year's sales then sales and labor input will be simultaneously determined, causing an upward bias to labor input's estimate. Indeed, running a simple regression with year totals (not shown) gives an improbably large labor input elasticity estimate: 1.02 .

An alternative approach, also implemented in previous studies of the management input (e.g., Black and Lynch 2004, Bloom and Van Reenen's 2007), is to include store fixed effects in the production function to control for the possible correlation between labor input, which varies by week, and store-specific unobservables (such as last year's sales shock), which are fixed for at least one year. Having weekly data on sales and employment, we also allow for dynamics in the response of sales to changes in labor input. For instance, hours spent on shelving in one week may increase sales in the following weeks. Our inclusion of lags will improve the quality of the estimates for labor input by allowing for differences between short- and long-run labor input elasticities. However, the lags do not change the regression estimates for the KBIs materially.

Because, like unobservables, management, store space, and other controls are also fixed throughout the year, introducing store fixed effects necessitates a two-stage estimation procedure as follows. At the first stage we obtain the estimates for the short- and long- run labor input elasticities, $\hat{\alpha}_{1}$ and $\left(\hat{\alpha}_{1}+\hat{\alpha}_{2}\right) /(1-\hat{\gamma})$, by running the sales equation with store fixed effects:

$$
\begin{aligned}
& \ln (\text { sales })_{i t}=\gamma \ln (\text { sales })_{i t-1}+\alpha_{1} \ln (\text { labor })_{i t} \\
& +\alpha_{2} \ln (\text { labor })_{i t-1}+\text { week dummy } \\
& + \text { fixed effect }_{i}+\text { error }_{i t}^{1 \text { st stage }} \text {, }
\end{aligned}
$$

where $i=1 \ldots 245$ and $t=1 \ldots 52$ are the store and week counters. The elasticities' standard errors are calculated by using the delta method. ${ }^{1}$ We then proceed to the second stage, where we use the estimated fixed effects as the dependent variable, as follows:

$$
\begin{aligned}
\text { fixed effect }_{i}= & \beta_{1} \ln \left(\text { space }_{i}+\beta_{2} \mathrm{KBI}_{i}+\beta_{3}\right. \text { other controls } \\
& + \text { error }_{i}^{2 \text { nd stage }} .
\end{aligned}
$$

It is at this stage that we obtain the estimates $\left(\beta_{2}\right)$ for the KBI grades.

The literature identifies three other estimation issues. First, the labor input elasticity may be overestimated since sales and labor input may be simultaneously determined by an unobserved process (Blundell

${ }^{1}$ To see that $\hat{\alpha}_{1}$ and $\left(\hat{\alpha}_{1}+\hat{\alpha}_{2}\right) /(1-\hat{\gamma})$ represent the short- and longrun labor input elasticities, it is enough to rewrite Equation (1) in the error-correction form,

$$
\begin{aligned}
\Delta \ln (\text { sales })_{i t}= & \alpha_{1} \Delta \ln (\text { labor })_{i t}+\text { error }_{i t}^{1 \text { st stage }} \\
& -(1-\gamma)\left(\begin{array}{c}
\ln (\text { sales })_{i t-1}-\frac{\alpha_{1}+\alpha_{2}}{1-\gamma} \ln (\text { labor })_{i t-1} \\
-\frac{1}{1-\gamma} \text { week dummy }_{t}-\frac{1}{1-\gamma} \text { fixed effect }_{i}
\end{array}\right) .
\end{aligned}
$$


et al. 2000), for instance, change in consumer tastes. To correct for the upward bias, following Bloom and Van Reenen's (2007), we instrument labor input with its lags from 2 to 5 . We find, however, that instrumentation makes little difference to the estimates, presumably because using data from a single company helps ensure that time-varying unobservables are the same for all stores and thus can be captured by the week dummies. Second, estimating a dynamic equation such as (1) on panel data produces a bias to some of the estimates, mainly $\gamma$ (Nickell 1981), which can be corrected by instrumenting the lagged dependent variable with its earlier lags. We choose, however, not to instrument it because of the loss of efficiency that the instrumenting would entail, while the bias in question is negligible in long (52 weeks) panels such as ours (see Judson and Owen 1999 for Monte-Carlo simulations of the bias). Finally, we test for autocorrelation in the first-stage regression residual, finding which would imply an incorrectly specified model because in that case the error term would be correlated with one of the regression variables, $\ln (\text { sales })_{i t-1}$. Our first-stage regression passes this test.

\subsection{Causality or Association?}

As noted earlier (Lucas 1978), it is profit-maximizing for the company to allocate store managers with better skills to bigger and better-performing stores because store size and efficiency magnify the contribution of more skilled managers to the total profit. The consequence of such nonrandom allocation will be an overestimate of the causal effect of manager skills on sales unless we can control for all of the relevant factors or use suitable instruments to recover the causal effect. Still, in the absence of such instruments and controls, we can reduce this bias by introducing a proxy for the unobservables as we now explain.

Suppose that, holding all else constant, log sales depend on log management input $(x)$, an unobserved store characteristic $(z)$, and random noise $(\epsilon)$ that is uncorrelated with both $x$ and $z$,

$$
\ln (\text { sales })=\delta \cdot x+z+\epsilon .
$$

Because $z$ is not observed, we estimate

$$
\ln (\text { sales })=\tilde{\delta} \cdot x+e,
$$

where $e=z+\epsilon$. Applying the omitted variable bias formula, the expected value of the effect of management on sales is

$$
\tilde{\delta}=\delta+\frac{\operatorname{cov}(x, z)}{\operatorname{var}(x)},
$$

which is biased upward by $\operatorname{cov}(x, z) / \operatorname{var}(x)$ to the extent that better managers (higher $x$ ) are allocated to intrinsically more-productive stores (higher $z$ ).
To illustrate this bias on our data, we run partial correlations between the commercial awareness score $(0=$ "development need," $1=$ "capable," $2=$ "strength") as the measure of management input $(x)$ and the store's annual labor input (denoted $z^{*}$ ). The store's annual labor input is used here because it is closely correlated with the unobserved $z$, holding all other inputs in the sales function fixed. ${ }^{2}$ The estimate for the bias, $\operatorname{cov}\left(x, z^{*}\right) / \operatorname{var}(x)$, is 0.062 . This estimate tells us that, if not corrected for the bias, the effect of management on sales will be overestimated, but it is not informative enough about the magnitude of the bias because we do not observe the distribution of the true $z$.

Adding store-specific fixed effects, as is done in Capelli and Neumark (2001) and Ichniowski et al. (1997), would eliminate this bias, but then the effect of management would not be separately identified because management input does not vary within store. We can, however, reduce the bias and allow for some independent variation in management input by grouping stores likely to have similar unobservables. Store size measured as annual labor input is an appropriate criterion for grouping because, as we showed above, it is correlated with the unobservables that we aim to capture. In fact, grouping stores into four size quartiles and adding a fixed effect for each quartile reduces the estimated bias by $75 \%$, from 0.062 to 0.016 , implying that stores within the same size quartile are quite similar in terms of the unobservables. Our procedure thus corrects for a large part of the nonrandom manager selection bias, bringing the estimates for manager skills closer to their true causal effect.

\section{Regression Results for Store Sales}

Table 4 presents the regression results from both stages of the estimation procedure together. The first-stage results are the same for all specifications reported in this table. The short- and longrun labor input elasticities (0.279 and 0.516, respectively) differ in a predictable direction, implying that

${ }^{2}$ Consider a Cobb-Douglas sales function with three inputs, labor $(L)$, capital $(K)$, and management $(X)$, and a total factor productivity component $(A)$ summarising all other influences on output. Maximising expected sales across the stores, $\sum_{i=1}^{N} A_{i} \cdot L_{i}^{\alpha} \cdot K_{i}^{\beta}$. $X_{i}^{\delta} \cdot e^{z_{i}}$, subject to the budget constraint, $\sum_{i=1}^{N}\left(w_{1 i} \cdot L_{i}+w_{2 i} \cdot X_{i}\right)=B$, with wages $\left(w_{1 i}, w_{2 i}\right)$ given and $K$ fixed, a typical first-order condition for labor is

$$
\begin{aligned}
\ln L_{i}= & -\frac{1}{1-\alpha-\delta} \cdot\left(\ln \lambda+(1-\delta) \ln \frac{w_{1 i}}{\alpha}+\delta \ln \frac{w_{2 i}}{\delta}\right) \\
& +\frac{1}{1-\alpha-\delta} \ln A_{i}+\frac{\beta}{1-\alpha-\delta} \ln K_{i}+\frac{1}{1-\alpha-\delta} \cdot z_{i},
\end{aligned}
$$

where $\lambda$ is the Lagrange multiplier. So, controlling for capital input, wages and $A$, the store's annual labor input is simply linked to the unobserved store characteristic $z$. 
Table 4 Regression Results for Sales

\begin{tabular}{|c|c|c|c|c|c|c|c|}
\hline Dependent variable: Log sales & $(1)^{\mathrm{a}}$ & $(2)$ & (3) & (4) & $(5)$ & $(6)$ & (7) \\
\hline \multicolumn{8}{|c|}{ First-stage equation $(1)^{b}$} \\
\hline Labor, short-run & & & & $0.279 * * *$ & & & \\
\hline Labor, long-run & & & & $0.516^{* * *}$ & & & \\
\hline Adjusted $R^{2}$ & & & & 0.678 & & & \\
\hline Number of observations & & & & 12,671 & & & \\
\hline \multicolumn{8}{|c|}{ Second-stage equation (2) } \\
\hline \multicolumn{8}{|c|}{ Management grades ${ }^{\mathrm{c}}$} \\
\hline \multicolumn{8}{|l|}{ Sales focus } \\
\hline "Capable" & $0.056^{* *}$ & -0.002 & 0.004 & 0.011 & 0.011 & 0.004 & 0.004 \\
\hline "Strength" & $0.114^{* * *}$ & 0.029 & 0.029 & 0.029 & 0.030 & 0.030 & 0.016 \\
\hline \multicolumn{8}{|l|}{ Commercial awareness } \\
\hline "Capable" & $0.099 * * *$ & $0.100^{* * *}$ & & & & $0.092^{* * *}$ & $0.074^{* *}$ \\
\hline "Strength" & $0.176^{* * *}$ & $0.165^{* * *}$ & & & & $0.139^{* * *}$ & $0.120^{* * *}$ \\
\hline $\begin{array}{c}\text { Commercial awareness score }(0=\text { "development need," } \\
1=\text { "capable," } 2=\text { "strength") }\end{array}$ & & $0.078^{* * *}$ & $0.058^{*}$ & $0.067^{* * *}$ & & & \\
\hline \multicolumn{8}{|l|}{ Leadership } \\
\hline "Capable" & $0.078^{* * *}$ & $0.056^{* *}$ & 0.053 & 0.026 & 0.027 & 0.028 & 0.001 \\
\hline "Strength" & $0.092^{* * *}$ & 0.022 & 0.016 & -0.015 & -0.015 & -0.012 & -0.026 \\
\hline \multicolumn{8}{|l|}{ Developing people } \\
\hline "Capable" & 0.014 & -0.023 & -0.019 & -0.028 & -0.030 & -0.035 & -0.046 \\
\hline "Strength" & $0.074^{* * *}$ & 0.002 & -0.003 & -0.022 & -0.024 & -0.024 & -0.026 \\
\hline \multicolumn{8}{|l|}{ Drive and pers. development } \\
\hline "Capable" & 0.032 & 0.008 & 0.010 & -0.014 & -0.014 & -0.017 & -0.020 \\
\hline "Strength" & $0.079^{* * *}$ & 0.024 & 0.034 & -0.010 & -0.006 & -0.011 & -0.018 \\
\hline \multicolumn{8}{|l|}{ Planning and organizing } \\
\hline "Capable" & -0.015 & -0.056 & -0.051 & -0.042 & -0.038 & -0.043 & -0.029 \\
\hline "Strength" & 0.032 & -0.064 & -0.062 & -0.039 & -0.040 & -0.044 & -0.034 \\
\hline \multicolumn{8}{|l|}{ Overall grade (relative to $\mathrm{C}$ ) } \\
\hline $\begin{array}{l}\text { A or } B(15.1 \% \text { of sample }) \\
\text { D or } E(19.6 \%)\end{array}$ & & & & & & & $\begin{array}{c}0.013 \\
-0.083^{* * *}\end{array}$ \\
\hline \multicolumn{8}{|c|}{ Other controls } \\
\hline Store space & & $0.284^{* * *}$ & $0.282^{* * *}$ & $0.113^{*}$ & $0.115^{* *}$ & $0.116^{* *}$ & 0.109 \\
\hline \multicolumn{8}{|l|}{ Weekly contract hours ${ }^{d}$} \\
\hline $0-4$ & & $0.251^{* * *}$ & $0.280^{*}$ & $0.209^{*}$ & $0.213^{*}$ & 0.195 & $0.216^{*}$ \\
\hline $5-14$ & & 0.147 & 0.163 & 0.180 & 0.182 & 0.176 & 0.188 \\
\hline $15-29$ & & $0.168^{*}$ & 0.198 & 0.151 & 0.161 & 0.147 & 0.166 \\
\hline In(area average pay) & & $0.770^{\text {*** }}$ & $0.737^{*}$ & $0.543^{*}$ & 0.517 & 0.526 & 0.427 \\
\hline Area unemployment rate & & $-2.449 *$ & -2.268 & -1.591 & -1.455 & -1.464 & -1.183 \\
\hline In(store assistant relative pay) & & $0.703^{* * *}$ & $0.724^{* *}$ & $0.645^{* *}$ & $0.617^{* *}$ & $0.623^{* *}$ & $0.500^{*}$ \\
\hline \multicolumn{8}{|l|}{ Competitors in catchment area } \\
\hline $18-30$ & & 0.012 & 0.015 & -0.021 & -0.023 & -0.025 & 0.005 \\
\hline $31-51$ & & $0.143^{* * *}$ & $0.141^{* * *}$ & 0.010 & 0.008 & 0.011 & 0.037 \\
\hline $52+$ & & $0.248^{* * *}$ & $0.237^{* * *}$ & 0.073 & 0.072 & 0.081 & $0.094^{*}$ \\
\hline Store size quartile fixed effects ${ }^{\dagger}$ & No & No & No & Yes & Yes & Yes & Yes \\
\hline Quartile effects $\times$ comm. awareness score & No & No & No & Yes & No & No & No \\
\hline Adjusted $R^{2}$ & & 0.785 & 0.785 & 0.872 & 0.873 & 0.873 & 0.877 \\
\hline Number of observations & & & & 245 & & & \\
\hline
\end{tabular}

Note. Other controls in each specification include week dummies, area manager dummies (20), location, brand, average employee age, tenure, turnover, share of male employees, share of children's products in total.

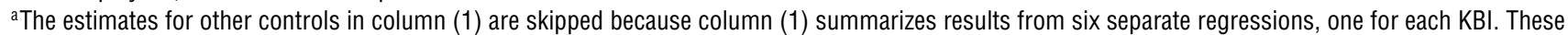
are available on request.

${ }^{\mathrm{b}}$ Observations for the first stage are store weeks; labor input is instrumented with its lags from 2 to 5.

"Development need" is the base category.

'Share of employees working $30+$ hours per week is the base category.

${ }^{\mathrm{e}}$ The number of competitors fewer than 17 (first quartile of distribution) is the base category.

'The store quartile fixed effects are four dummies picking up the annual labor input size quartile in which each store falls.

${ }^{* * *},{ }^{* *}$, and ${ }^{*}$ denote estimates significant at $1 \%, 5 \%$, and $10 \%$, respectively.

it takes longer than one week for sales to react to an extra hour worked. The reduction in the magnitude of the long-run labor input elasticity to 0.516 from 1.02 estimated earlier is consistent with our hypothesis that last year's sales shocks persist. The sum of the long-run labor elasticity, 0.516, plus the capital (store space) elasticity of approximately 0.11 in our preferred specification (column (6)) gives a returns to scale value below unity (as required for the company's profit maximization problem to have 
an interior solution). Thus, our two-step procedure, which uses weekly, within-store variation in labor input-independent of last year's sales shocks-is required to derive reasonable labor input elasticity and returns to scale parameters.

Turning to the KBI grades, we first enter them into the sales equation one by one (column (1)) and then together (columns (2)-(7)) with the aim of detecting overlaps and finding which one is most important. Looking at column (1), which contains estimates from six separate regressions, one for each KBI, most KBIs are individually significant. Yet whenever all six KBIs are included together (for instance, in column (2)) only commercial awareness remains significant. The loss of individual significance of KBI grades indicates substantial intercorrelations between different KBIs, probably as a result of overlapping definitions. Yet evidently it is the special characteristics of commercial awareness that are important for sales because its coefficients are similar whether entered separately or jointly. As noted above, these characteristics consist mainly of entrepreneurial skills, such as monitoring local competition and efficient use of resources subject to the wage budget rule. These skills are not assessed based on sales, so the estimates for commercial awareness are unlikely to be driven by reverse causality.

Our next step is to address the issue of nonrandom allocation of managers to stores, which, as discussed in $\$ 3.5$, results in an upward bias for the KBI estimates. We concentrate on the most important commercial awareness KBI, beginning with column (3), where, for simplicity, the commercial awareness score is used instead of grade dummies. Following the procedure outlined in \$3.5, we introduce quartile fixed effects as partial controls for the unobservables, and their cross-products with the commercial awareness score, thus allowing each quartile of store size to have its own bias to the commercial awareness score estimate (column (4)). We see that, consistent with the predicted upward bias, the estimate for the commercial awareness score goes down from 0.078 in column (3) to 0.058 in column (4). The quartile fixed effects are highly significant, but the cross-products are not (restrictions test $p$-value $=0.70$ ), so we skip them in columns (5)-(7). Their insignificance implies that the bias due to nonrandom allocation of managers to stores is approximately the same for big stores as for small. Comparing the estimates for the commercial awareness score in the specifications with the quartile fixed effects $(0.067$, column (5)) and without $(0.078$, column (3)) shows that this bias is not large. Turning to our preferred specification with KBI grade dummies (column (6)), we see that controlling for quartile fixed effects reduces the estimates for grade capable from 0.100 (column (2)) to 0.092, i.e.,
$9.2 \%$ higher sales than grade development need, and for grade strength from 0.165 to 0.139 .

In addition to individual KBIs, we introduce dummies for the overall grade (an indicator based on the sum of KBI scores; see §3.3) to find out whether there is a joint effect of several KBIs not captured by their individual estimates. We find (column (7)) that sets of different competencies matter beyond their individual components, supporting the management practice complementarity view (Macduffie 1995, Ichniowski et al. 1997). Our results imply that failing to develop some minimal proficiency in all competence areas (overall grade C) results in $8.3 \%$ lower sales. Yet excelling in overall performance (grade A or B) as opposed to particular competencies brings little additional benefit (1.3\%, and insignificant). Still, in all specifications, the commercial awareness KBI retains its importance.

Turning to the controls, we see that paying higher wages relative to competitors' enters positively, reflecting presumably the better quality of attracted workers. Sales tend to be higher in wealthier areas and in areas where there are clusters of competitors. Importantly, many controls lose magnitude and significance once quartile fixed effects, proxying for unobservables in our analysis, are introduced. The case of local competition is instructive. Its loss of importance suggests that much of its correlation with sales was due to its correlation with the unobservables such as special location, which are now better controlled. Thus, the implication is that it is not that high competition results in more sales, but rather that more competitors are lured to more advantageous locations. ${ }^{3}$ Picking up location, the quartile fixed effects also contribute to the control for capital, whose estimate goes down as we introduce them.

\section{Managing the Managers}

We have seen that the company has a substantial minority (approximately 18\%, Table 3) of underperforming store managers, i.e., those with grade development need for commercial awareness, whose stores generate significantly less sales than comparable stores with more capable managers. To some extent, the wide distribution of manager skill grades within our company parallels Bloom and Van Reenen's (2007) cross-company distribution, which reveals "huge heterogeneity" (p. 1379) and a long tail of managers with low skill ratings. However, their

\footnotetext{
${ }^{3}$ It might be thought, alternatively, that the effect of competition on performance fully manifests itself in better management (as in Griffiths 2001). However, competition is insignificant in the size quartile fixed effects specification even when the management KBIs are excluded.
} 
Table 5

Determinants of Manager to Store Allocation

Dependent variable:

Commercial awareness score

(1)

(2)

(3)

(4)

\begin{tabular}{lrrrr}
\hline Log annual labor input & $0.372^{* * *}$ & & $0.303^{* * *}$ & $0.355^{* * *}$ \\
Competitors in catchment area & & & & \\
$\quad$ 18-30 & & 0.063 & -0.058 & -0.033 \\
$31-51$ & & 0.111 & -0.106 & -0.092 \\
$52+$ & & $0.510^{* * *}$ & 0.172 & 0.152 \\
In(area average pay) & & & & 0.128 \\
Store type and location dummies & No & No & No & Yes \\
Adjusted $R^{2}$ & 0.093 & 0.079 & 0.104 & 0.101 \\
Number of observations & & & \multicolumn{2}{c}{245} \\
\end{tabular}

Note. The commercial awareness score takes the value 0 for "development need," 1 for "capable," and 2 for "strength."

${ }^{* * *},{ }^{* *}$, and $*$ denote estimates significant at $1 \%, 5 \%$, and $10 \%$, respectively.

finding that poor family-owned company management accounts for some of this tail clearly cannot apply in our case where ownership is held constant. Their other finding, that more intense competition leads to weeding out bad managers, seems more applicable but requires an investigation into the practices of managing store managers, which is the topic of the present section.

We consider three broad ways to manage store managers, first by matching managers to appropriate stores, second by weeding out the poor managers as they reveal themselves, and finally by providing incentives to the existing management team. As regards matching managers to stores, we report in Table 5 the results of regressing the managers' commercial awareness score on their store size (measured as $\log$ annual labor input) and area characteristics. We find, consistent with Lucas's (1978) theory, that store size measured in $\log$ annual labor input is the single most important correlate of manager skill grade in a given store, whether other possible factors, including local competition, are present (columns (2)-(4)) or not (column (1)). That said, the estimated elasticity of commercial awareness score to store size (0.355) is rather small, implying a mere 0.3 standard deviation increase in the average commercial awareness score with a one standard deviation increase in store size. (Ordered probit and logit estimators that we have used as alternatives to the ordinary least squares estimator in Table 5 give similarly low elasticity.) Thus, the allocation of managers to stores does not look very precise.

Turning to the possibility of weeding out the poor managers, the distribution of manager skill grades is hard to improve for several reasons. First, store managers tend to be attached to their locality, and with an average salary of $£ 21,000$ per year (just under the national average) attracting new talent is difficult. Second, as our top management informants explained, it is expensive in the UK legal context to weed out the bad managers through dismissal. The option of demotion is also disruptive. Third, management talent is difficult to identify, especially as it appears to be highly company specific (see discussion of the pay regressions below). Therefore, because the company is unable to improve the quality of its store manager pool easily, it is left with the option of incentivizing its managers to perform to the best of their ability, as we show next.

\subsection{A Model of Incentive Pay}

Consider an incentive pay model in the spirit of Holmström's (1979) (see also Holmström and Milgrom 1987), with a risk-neutral company and a risk-averse manager, but which includes manager skill. In year $t$, the manager produces output $(y)$, which depends on her effort $(\epsilon)$, observable to her only, skill level (c), observable to both parties, and the annual random shock term $(\eta)$, observable to none: ${ }^{4}$

$$
\begin{gathered}
y_{t}=\eta_{t} \quad \text { if } \epsilon_{t}=0, \\
y_{t}=\epsilon_{t}+c+\eta_{t} \quad \text { if } \epsilon_{t}>0 .
\end{gathered}
$$

The manager expects a wage $w_{t+1}$ to be paid at the beginning of the next period, which in part depends on her past period's output,

$$
\begin{gathered}
w_{t+1}=\alpha+\beta \eta_{t} \quad \text { if } \epsilon_{t}=0, \\
w_{t+1}=\alpha+\beta\left(\epsilon_{t}+c+\eta_{t}\right) \quad \text { if } \epsilon_{t}>0 .
\end{gathered}
$$

She chooses the level of effort,

$$
\epsilon_{t}^{*}=\frac{\beta}{\delta},
$$

which maximizes her utility function,

$$
U\left(w_{t+1}, \epsilon_{t}\right)=E\left(w_{t+1}\right)-\delta \cdot \frac{\epsilon_{t}^{2}}{2}-\lambda \cdot \operatorname{var}\left(w_{t+1}\right),
$$

where parameters $\delta>0$ and $\lambda>0$ represent the cost of effort and aversion to uncertainty over the realized value of output. ${ }^{5}$ She will work only if her utility given her chosen effort is no less than her utility from working elsewhere, $\bar{u}\left(\mathbf{h}_{t}, c\right)$, which we assume to depend on her skill level $c$ and her outside options (vector $\mathbf{h}_{t}$ ).

The company maximizes its expected profit defined as the difference between the output in period $t$

\footnotetext{
${ }^{4}$ There are, of course, other determinants of output, such as store size, but, assuming that their contribution to output does not depend on manager's effort, their "prices" can be agreed on in advance rather than determined endogenously within the incentive pay model. Therefore, we abstract from them for now for the ease of exposition.

${ }^{5}$ Our assumption that the cost of effort, $\delta>0$, is invariant with respect to manager skill level is admittedly heroic, but we test it and find it to hold (results are available upon request).
} 
and the wage to be paid to the manager, having worked out the manager's chosen level of effort $\epsilon_{t}^{*}$ (Equation (3)). The result of a strategic interaction between the company and the manager is a wage offer with the following parameters:

$$
\begin{gathered}
\alpha_{t}^{*}=\bar{u}\left(\mathbf{h}_{t}, c\right)-\frac{c}{1+2 \lambda \delta \cdot \operatorname{var}\left(\eta_{t}\right)} \\
-\frac{1-2 \lambda \delta \cdot \operatorname{var}\left(\eta_{t}\right)}{2 \delta\left(1+2 \lambda \delta \cdot \operatorname{var}\left(\eta_{t}\right)\right)^{2}} \\
\beta_{t}^{*}=\frac{1}{1+2 \lambda \delta \cdot \operatorname{var}\left(\eta_{t}\right)}
\end{gathered}
$$

simplifying to

$$
w_{t+1}=\bar{u}\left(\mathbf{h}_{t}, c\right)+\frac{1}{2 \delta \beta_{t}^{*}}+\beta_{t}^{*} \eta_{t} .
$$

For the empirically relevant case of $0<\beta_{t}^{*}<1$, the model implies that pay is determined by (i) the manager's outside alternatives $\left(\bar{u}\left(\mathbf{h}_{t}, c\right)\right)$ and (ii) meeting sales expectations set by HQ given the manager's skill level and other inputs $\left(\eta_{t}\right)$. If these expectations are not met, the manager takes a proportionate $\beta_{t}^{*}$ cut in her next year's pay, and conversely if expectations are exceeded. The dependence of a manager's pay on meeting HQ's expectations helps ensure that she applies herself even if close monitoring of her activities is not possible. We expect $\beta_{t}^{*}$ to be less than unity because of manager risk aversion $(\lambda>0)$. The model thus also implies that managers are "insured" by bearing only a fraction of the shock.

\subsection{Store Manager Pay Regression Specification}

We now develop a suitable proxy for $\eta_{t}$ and test the above model by estimating the manager pay equation (5). It might be thought that Equation (5) can be estimated directly by using the available store and manager data and the estimated second-stage error term from the sales regression (error ${ }_{i}^{2 \text { nd stage }}$ ) as a proxy for the annual random shock term $\eta$. The problem with this direct approach is that error ${ }_{i}^{\text {nd stage }}$ contains components observable to both $\mathrm{HQ}$ and store managers (and therefore not part of the unexpected sales) but not observable to us. Indeed, we show in Table 6 that error $_{i}^{2 \text { nd stage }}$ is not a significant predictor of pay. However, adding some intuitive structure to it brings back its significance.

Assume that the current (2005) year's error term from Equation (2) is a function of the last year's error term plus our annual random shock term $(\eta)$ :

$$
\operatorname{error}_{i}^{2 \text { nd stage }}=\phi \cdot \text { error }_{i,-1}^{2 \text { nd stage }}+\eta_{i},
$$

\begin{tabular}{|c|c|c|c|}
\hline Dependent variable: Log 2006 pay & (1) & $(2)$ & (3) \\
\hline $\begin{array}{l}\text { Error term from sales equation } \\
\qquad\left(\text { error }^{2 \text { nd stage }}\right)^{\mathrm{a}}\end{array}$ & 0.033 & & \\
\hline Log unexpected sales $(\eta)^{\mathrm{b}}$ & & $0.233^{* * *}$ & $0.238 *$ \\
\hline Log average pay for similar job & $0.343^{* * *}$ & $0.354 * * *$ & \\
\hline Log FTE personnel & $0.281^{* * *}$ & $0.284^{* * *}$ & \\
\hline Store manager age & $0.010^{*}$ & $0.011^{*}$ & \\
\hline Store manager age ${ }^{2} \times 100$ & -0.012 & $-0.012^{*}$ & \\
\hline Experience with company & 0.002 & 0.002 & \\
\hline Store manager is male & $0.047^{* *}$ & $0.043^{* *}$ & \\
\hline \multicolumn{4}{|l|}{ Sales focus } \\
\hline "Capable" & -0.015 & -0.017 & 0.012 \\
\hline "Strength" & 0.005 & 0.003 & 0.039 \\
\hline \multicolumn{4}{|l|}{ Commercial awareness } \\
\hline "Capable" & 0.020 & 0.019 & 0.029 \\
\hline "Strength" & 0.026 & 0.025 & 0.070 \\
\hline \multicolumn{4}{|l|}{ Leadership } \\
\hline "Capable" & -0.008 & -0.006 & -0.011 \\
\hline "Strength" & 0.005 & 0.006 & 0.063 \\
\hline \multicolumn{4}{|l|}{ Developing people } \\
\hline "Capable" & 0.011 & 0.011 & 0.001 \\
\hline "Strength" & 0.050 & $0.049 *$ & $0.118^{*}$ \\
\hline \multicolumn{4}{|l|}{ Drive and personal development } \\
\hline "Capable" & 0.005 & 0.004 & 0.010 \\
\hline "Strength" & -0.030 & -0.030 & -0.021 \\
\hline \multicolumn{4}{|l|}{ Planning and organizing } \\
\hline "Capable" & -0.024 & -0.023 & -0.057 \\
\hline "Strength" & -0.042 & -0.041 & -0.041 \\
\hline Competitors in the catchment area & Yes & Yes & No \\
\hline Adjusted $R^{2}$ & 0.695 & 0.705 & 0.703 \\
\hline Number of observations & & 236 & \\
\hline
\end{tabular}

where $0<\phi<1$ is the autoregression parameter. This assumption is reasonable because many unobservables (for instance, location or tastes) can have
Table 6 Regression Results for the Store Manager Pay Equation (5)

${ }^{a} e^{2} r r o{ }^{2 n d}$ stage is the error term from the second-stage sales equation (2).

${ }^{\mathrm{b}} \eta$ is the error term from the augmented second-stage sales equation (8).

$* * *, * *$, and $*$ denote estimates significant at $1 \%, 5 \%$, and $10 \%$, respectively.

effects on sales lasting longer than a year. ${ }^{6}$ Once capital, management, and other fixed inputs have been set, the only way for a store to adapt to changes in trading environment is to adjust its annual labor input. Part of this adjustment happens in response to changes in the expected value of the unobservable term, $E\left(\right.$ error $\left._{i}^{2 \text { nd stage }}\right)=\phi \cdot$ error $_{i,-1}^{2 \text { nd stage }}$ (Equation (6)), implying that labor input in the current year is a positive function of the last year's unexpected sales, error $_{i,-1}^{2 \text { nd stage }}$.

To estimate the annual random shock term $\eta$, we take advantage of the fact that, with capital and management inputs fixed and the trading environment exogenous, error ${ }_{i,-1}^{2 \text { nd stage }}$ is uncorrelated with all of the observed variables apart from log annual labor input, $\ln L_{i}=\ln \left(\sum_{k=1}^{52}\right.$ labor $\left._{i k}\right)$. Therefore, we can regress annual labor input on the rest of the observed

\footnotetext{
${ }^{6}$ As evidence for the persistence of unexpected sales, recall the result from $\$ 3.4$, that in the absence of store fixed effects the estimate for labor input elasticity is biased upward because of labor input's correlation with store unobservables containing last year's unexpected sales.
} 
variables that are constant throughout the year (all of the controls in Equation (2) including the KBIs and quartile fixed effects, denoted as vector $\mathbf{x}_{i}$ ),

$$
\ln L_{i}=\mathbf{x}_{i} \theta+\xi_{i}
$$

and use the estimated residuals from this regression $\left(\hat{\xi}_{i}\right)$ as a proxy for error ${ }_{i,-1}^{2 \text { nd stage }}$ in Equation (6). We then recover $\eta$ as the residual of the second-stage sales equation (2), which we rerun with $\hat{\xi}_{i}$ included as a separate regressor:

$$
\begin{aligned}
\text { fixe }_{\text {effect }_{i}=} & \beta_{1} \ln (\text { space })_{i}+\beta_{2} \mathrm{KBI}_{i} \\
& +\beta_{3} \text { other controls }{ }_{i}+\hat{\xi}_{i}+\eta_{i} .
\end{aligned}
$$

Note that, because $\hat{\xi}_{i}$ is independent of all of the observed regression variables in the sales equation by construction (see Equation (7)), all of the estimates in Table 4 remain the same.

\subsection{Manager Pay Regression Results}

Table 6 reports the regression results for log store manager total annual pay in 2006. As can be seen from column (1), the annual random shock term measured simply as the second-stage error (error ${ }^{2 \text { nd stage }}$ ) from the sales regression is unimportant for store manager pay. Consequently, our procedure for recovering $\eta$ via Equation (8) is indeed necessary to reveal the incentives available to store managers. Columns (2) and (3) then demonstrate that, once we correct error $^{\text {2nd stage }}$ for persistent unobservables that both managers and HQ can predict, it becomes a significant determinant of pay. This result supports our incentive pay model (Equation (5)).

The incentives to perform come from the possibility of failing to meet sales expectations, which then means a cut in the next year's pay. The 0.233 elasticity result shows the proportion in which unexpected sales gains and losses are shared between the managers and the company. It is the manager's aversion to risk $(\lambda>0$, see Equation (4)) that limits full sharing. Thus, a $10 \%$ change in $\eta$ (not unusual and close to $\eta^{\prime}$ s standard deviation of 0.11 ) results in a $2.3 \%$ change in a store manager's pay.

As can be seen from Table 6, there is no significant link between pay and commercial awareness. This finding parallels that of Bloom and Van Reenen's (2007, p. 1386), who also find no link between the management score in a firm and its CEO's pay. Comparison of columns (2) and (3) shows that there is no link whether or not we control for other potential correlates of manager skill grade, such as manager age and experience, or pay for a similar job and local competition, which proxy the outside opportunities available to managers. The implication is that the KBI commercial awareness measures a type of companyspecific manager skill that raises sales in company stores as we have seen but that is not easily tradable on the outside labor market.

Turning to the other determinants of manager pay, we see that pay is $4.3 \%$ higher for male store managers and for those living in areas with higher managerial pay (an elasticity of 0.354 ) - presumably reflecting the more generous outside options available to them. Managing more workers attracts a significant premium as well (0.284), which is consistent with the greater responsibilities of running a larger store and has nothing to do with rewarding skill.

\section{Discussion}

\subsection{Management and Economic Performance: Some Illustrations}

We find that the most important management skill is commercial awareness, which rewards efficient use of store space and workforce, sticking to the wage budget, and watching competitors. Variation in commercial awareness is responsible for a sizable portion of variation in labor productivity. Using the results from our preferred specification (column (6) in Table 4) we find that moving from the bottom quartile of the distribution of commercial awareness (i.e., development need, $18 \%$ of the sample) to the top quartile (strength, $26 \%$ ) is associated with a $13.9 \%$ improvement in sales, which, holding all factor inputs constant, results in the same improvement in labor productivity. With the interquartile range in store labor productivity at $40 \%$, commercial awareness accounts for approximately $35 \%(=13.9 / 40)$ of it. Continuing to assume the cost of sales to be a constant fraction of sales, we calculate the interquartile range of store total factor productivity (TFP) at $52 \%{ }^{7}$ hence, commercial awareness accounts for approximately $27 \%$ of the interquartile range in TFP.

Based on our regression results in Table 4 , let us now calculate the contribution to sales, $\Delta \Pi$, of manager skills higher than grade development need. We compare actual sales with some plausible counterfactuals as follows:

$$
\triangle \Pi=\sum_{k=0}^{2}\left(S_{k}^{a} G_{k}^{a}-S_{k}^{c} G_{k}^{c}\right)
$$

where $k=0,1,2$ is an indicator for commercial awareness grade $\left(0=\right.$ development need, $2=$ strength), $S_{k}^{a, c}$ are the actual $(a)$ and counterfactual (c) shares of

\footnotetext{
${ }^{7}$ We calculate TFP as the term $A$ from the Cobb-Douglas sales function, giving TFP $=\log$ sales $-0.516 \times \log$ number of hours worked $0.116 \times \log$ store space. This measure includes the contribution of the cost of sales, which, given that it is proportional to sales, does not affect TFP's interquartile range.
} 
worker-hours controlled by managers of grade $k$ in total, and $G_{k}^{a, c}$ are sales gains from higher management grades as compared with development need. We calculate the shares in total labor controlled by managers of different grades taking into account the differences in the size of the stores run by them, giving $S_{0}^{a}=0.134, S_{1}^{a}=0.509$, and $S_{2}^{a}=0.357$. From Table 4, $G_{0}^{a}=G_{0}^{c}=0, G_{1}^{a}=0.092$, and $G_{2}^{a}=0.139$. Suppose in the counterfactual that all managers are development need and are allocated to stores of the same size (that is, the share in total workforce controlled by each grade is equal to its share in the store manager skill grades distribution), so that $G_{0}^{c}=G_{1}^{c}=G_{2}^{c}=0$, and $S_{0}^{c}=0.176, S_{1}^{c}=0.563, S_{2}^{c}=0.261$ (see Table 3). Substituting these parameter values into Equation (9), we calculate the contribution at $9.6 \%$ of the actual sales, or $£ 23$ million for our sample.

Rewriting Equation (9), we can break down the total $9.6 \%$ contribution into two components: (i) that due to allocation of abler managers to bigger stores, holding gains from manager skills fixed, and (ii) that due to manager skills alone, holding store size equal for all managers, as follows:

$$
\Delta \Pi=\underbrace{\sum_{k=0}^{2} G_{k}^{a}\left(S_{k}^{a}-S_{k}^{c}\right)}_{\text {manager allocation }}+\underbrace{\sum_{k=0}^{2} S_{k}^{c}\left(G_{k}^{a}-G_{k}^{c}\right)}_{\text {manager skills }} .
$$

Given our chosen counterfactual, the first component (manager allocation) contributes only $0.9 \%$ of the total $9.6 \%$, and the second component makes up the remaining $8.7 \%$. The small contribution of manager allocation is consistent with the weak link between store size and commercial awareness score reported in Table 5. Moreover, the gains from manager allocation would remain limited even if abler managers always ran larger stores. For instance, even under a perfect correspondence of manager skill grade and store size rank, the total contribution of management skills to sales would be $10.8 \%$, a mere 1.2-point increase. Hence most of the sales gains from manager skills are independent of manager allocation by store size.

\subsection{Our Results and Other Studies}

Because store manager skills are highly specific and difficult to allocate among stores in the short run, our results help explain part of persistent interworkplace differences in productivity documented in the literature (Bartelsman and Doms 2000, Griffiths et al. 2006). It is instructive to compare our quantitative findings for management with those in the studies closest to ours. Our estimate of the share of the interquartile range of store TFP explained by store management, $27 \%$, is higher than Bloom and Van Reenen's's (2007) $10 \%-23 \%$. A possible explanation for this difference is that in a cross-company study such as theirs it is harder to control for company-specific factors affecting the relationship between management and productivity. As a result, this relationship may be blurred by "contingent management" (pp. 1371-1374), whereby practices are employed in different combinations as befits the company in question. The blurring occurs through combining many management practices, some of which are irrelevant to productivity, into one $z$-score, which effectively increases the measurement error component in the management regressor, therefore resulting in an attenuated estimate. Thus, when we put grades from all of the KBIs into a management $z$-score, its interquartile variation explains only a $6 \%$ movement in store productivity, thereby accounting for only $6 / 52=12 \%$ of the interquartile store TFP range, on a par with Bloom and Van Reenen's (2007) 10\%-23\%.

On the other hand, if aggregating individual competencies into a $z$-score attenuates the estimate for management because of measurement error, the question arises as to why our estimate of the share of the interquartile store productivity range explained by management (35\%) is close to the $40 \%$ found by Griffiths et al. (2006), which they derive from the management score aggregating over 11 measures. The reason seems to be fewer controls used in their study, a possibility that they do anticipate (p. 523). Thus, when we control only for labor input (as they do), the interquartile range in our management $z$-score explains nearly $70 \%$ of the interquartile store productivity range. Hence, the degree of detail in management data and statistical controls are equally important for the quantitative results of a management study.

Although most of our findings so far are consistent with the existing literature, our finding that competence in developing people is insignificant for sales seems to contradict the many studies showing the importance of high-performance HRM practices for firm performance (e.g., Ichniowski et al. 1997). There will be no contradiction, however, if one acknowledges the context of this company's business and the coexistence of different work systems within it. Such high-performance HRM practices as selection, training, and pay for performance are clearly important for core employees such as store managers. On the other hand, the sales assistants, who are predominantly part-time and inexpensive to replace, receive a much lighter HRM package from the company, and store managers can contribute only marginally. The coexistence of different work systems within one company-in our case, one for managers, another for sales assistants-is not unusual and has been found before (Leepak et al. 2007).

Turning to the manager pay results, our 0.23 estimate of the elasticity of pay with respect to the annual random shock term $\eta$ is slightly to the right of the range of estimates reported in the literature for the 
elasticity of CEO compensation to share returns, for example, Murphy's (1986) 0.14, Barro and Barro's (1990) 0.17, and Conyon and Murphy's (2000) 0.12 for the United Kingdom and 0.27 for the United States. Admittedly, we should not push comparisons from such different regression specifications too far. But, noting that our measure of $\eta$ may be regarded as similar to unexpected share returns, it is interesting that our estimate of the key incentive pay parameter appears to be broadly consistent with those previously reported.

Our results fit with the literature even more closely when it comes to the elasticity of manager pay with respect to firm (store) size. Our 0.284 estimate (Table 7) is well within the range of estimates reported: 0.22 for UK and 0.41 for U.S. firms (Conyon and Murphy's 2000); 0.37 for the top 1,000 U.S. corporations (Gabaix and Landier 2008); 0.32 for U.S. banks (Barro and Barro's 1990); 0.25 for Canadian publicly traded firms (Zhou 2000); and 0.25 for small U.S. firms (total assets up to 150 million 1993 U.S. dollars) in Cyert et al. (2002). This range is fairly narrow, considering differences in samples with respect to time, country, and industry, but our result fits neatly within it. The similarities between our pay results for middle managers and those from studies of CEOs are noteworthy and suggest that similar incentive mechanisms are at work at the middle as well as the top of the management hierarchy.

Finally, the manager pay results indicate that store manager skills in our company, particularly commercial awareness skills, are highly specific. They are important for sales and yet are not rewarded. This finding might seem surprising, but it accords exactly with the result in Bloom and Van Reenen's (2007), that CEO pay is not correlated with the management score (p. 1386). The implication is that the market for manager skills is more limited than might be expected. ${ }^{8}$ Admittedly, the description of commercial awareness (Table 2) appears to reveal a mixture of general skills (e.g., manpower planning) and specific skills (e.g., making the best use of a store's space), as envisaged in the human capital literature starting from Becker (1964). Yet, in our case of store managers, even though we seem to have the usual mixture of general and specific skills, these skills are more specific than might be thought.

\footnotetext{
${ }^{8}$ Hence we have Peter Drucker's (1974) classic statement that "It is an admission of bankruptcy for a big business to have to go on the outside to recruit into top management. It is also a desperate gamble" (p. 662). Thus, although much is made of the fluid market for managers, it seems in fact that most managers, from top managers (Bailey and Helfat 2003) down to our small store managers, are groomed within their firms.
}

\section{Conclusions}

In this paper we have looked into the black box of the middle management input in the production function of a firm and how this input is shaped by firmwide corporate governance practices. To do so, we have used data from a single firm. Our study thus shares the "insider econometrics" paradigm (Bartel et al. 2004) with other studies of the managementperformance link, such as Ichniowski et al. (1997) and Griffiths et al. (2006). To Crossland and Hambrick's (2007) consideration of "macro environment" constraints on management, our study can be seen as analyzing the micro environment. Let us summarize our findings and their implications.

We find a strong link between the company's measure of manager skill grade-the KBIs-and store sales performance, and we believe that this link is causal. The company's procedures are objective. Moreover, our allowing for store size effects provides a powerful control that reduces simultaneity between manager quality and store performance. The core of our study, the management measure and its effect on performance, is therefore meaningful.

The middle manager skills that we find most important are described by the KBI for commercial awareness. It encapsulates entrepreneurial skills, such as monitoring local competition and making efficient use of available resources. Differences in commercial awareness skills between store managers explain a considerable part of inter-store productivity differences: $27 \%-35 \%$, depending on the measure. The estimated total contribution to sales of manager skills above grade "development need" is $9.6 \%$ of the total actually observed. Thus, we find a significant contribution of middle (store) management to productivity. This result shows that "management matters" (Hambrick and Mason 1984) and specifically supports Kanter's (2004) research on the importance of the middle management tier.

At the same time, we find a long tail of poor managers, comparable with that found between firms (Bloom and Van Reenen's 2007), and this motivates our inquiry into the firmwide practices of managing the managers. Of these we have considered in detail allocating managers to stores of different size and incentivizing them through pay-for-performance contracts. We have found that abler managers tend to be assigned to larger stores, but their allocation is rather imprecise. However, our results also suggest that, even if allocation of managers to stores is perfect, securing the gains from manager skills still requires overcoming agency issues, especially when company operations are so dispersed geographically.

We show with an adaptation of Holmström's (1979) incentive pay model that the corporate governance practice of annual manager salary review helps accomplish this task. In support of our incentive pay 
model, we find that the process of salary review works to give an expected annual sales value for the manager in her store (which we assume is determined by the sales function that we estimate). Our findings show that positive/negative deviations are indeed proportionately rewarded/punished.

At the same time, we find that, while controlling manager effort, the company does not seem to reward middle manager skills, because higher-graded store managers do not receive higher pay all else equal. The implication here is that not only are top manager skills specific (Bailey and Helfat 2003) and generally difficult to trade or imitate, but so are middle manager skills. This finding therefore suggests that it makes sense for organizations to develop their management resources in-house-as a source of competitive advantage that cannot be easily bid away.

\section{Acknowledgments}

The authors thank the executives and staff at the study company for providing the company data and for many discussions on managing managers. They also thank department editor Olav Sorenson, the reviewers, and all those involved in preparing this paper for publication for helpful comments and patience. The authors are grateful for valuable suggestions from seminar participants at the University of Birmingham; the Hong Kong University; the CPB Netherlands Bureau for Economic Policy Analysis; Universitat Pompeu Fabra; the University of Tilburg; and the Work, Pensions, and Employment Group (WPEG); and particularly from John Heywood, Henry van der Wiel, Dinand Webbink, and Xiangdong Wei.

\section{References}

Bailey, E., C. Helfat. 2003. Management succession, human capital, and firm performance: An integrative analysis. Managerial Decision Econom. 24(2/3) 347-369.

Barro, J. R., R. J. Barro. 1990. Pay, performance, and turnover of bank CEOs. J. Labor Econom. 8(4) 448-481.

Bartel, A. P., C. Ichniowski, K. Shaw. 2004. Using "insider econometrics" to study productivity. Amer. Econom. Rev. 94(2) 217-223.

Bartelsman, E. J., M. Doms. 2000. Understanding productivity: Lessons from longitudinal microdata. J. Econom. Literature 38(3) 569-594.

Bebchuk, L. A., J. M. Fried. 2003. Executive compensation as an agency problem. J. Econom. Perspectives 17(3) 71-92.

Becker, G. S. 1964. Human Capital: A Theoretical and Empirical Analysis, with Special Reference to Education. University of Chicago Press, Chicago.

Bertrand, M., A. Shoar. 2003. Managing with style: The effect of managers on firm policies. Quart. J. Econom. 118(4) 1169-1208.

Black, S., L. Lynch. 2004. What's driving the new economy? The benefits of workplace innovation. Econom. J. 114(493) F97-F116.

Bloom, N., J. Van Reenen. 2007. Measuring and explaining management practices across firms and countries. Quart. J. Econom. 122(4) 1351-1408.

Blundell, R., S. Bond, F. Windmeijer. 2000. Estimation in dynamic panel data models: Improving on the performance of the standard GMM estimator. Working Paper W00/12, Institute for Fiscal Studies (IFS), London.
Capelli, P., D. Neumark. 2001. Do "high-performance" work practices improve establishment-level outcomes? Indust. Labor Relations Rev. 54(4) 737-775.

Carpenter, M., J. Wade. 2002. Microlevel opportunity structures as determinants of non-CEO pay. Acad. Management J. 45(6) 1085-1103.

Conyon, M. J., K. J. Murphy. 2000. The prince and the pauper? CEO pay in the United States and United Kingdom. Econom. J. 110(467) F640-F671.

Crossland, C., D. Hambrick. 2007. How national systems differ in their constraints on corporate executives: A study of CEO effects in three countries. Strategic Management J. 28(8) 767-789.

Cyert, R. M., S.-H. Kang, P. Kumar. 2002. Corporate governance, takeovers, and top-management compensation: Theory and evidence. Management Sci. 48(4) 453-469.

Drucker, P. 1974. Management: Tasks, Responsibilities, Practices. Harper and Row, New York.

Finkelstein, D., D. Hambrick, A. Cannella. 2009. Strategic Leadership: Theory and Research on Executives, Top Management Teams, and Boards. Oxford University Press, New York.

Gabaix, X., A. Landier. 2008. Why has CEO pay increased so much? Quart. J. Econom. 123(1) 49-100.

Griffiths, R. 2001. Product market competition, efficiency and agency costs: An empirical analysis. Working Paper WP01/12, Institute for Fiscal Studies, London.

Griffiths, R., J. Haskel, A. Neely. 2006. Why is productivity so dispersed? Oxford Rev. Econom. Policy 22(4) 513-525.

Hambrick, D., P. Mason. 1984. The organization as a reflection of its top managers. Acad. Management Rev. 9(2) 193-206.

Hayes, M., S. Schaefer. 1999. How much are differences in managerial ability worth? J. Accounting Econom. 27(2) 125-148.

Holcomb, T. R., R. M. Holmes, B. L. Connelly. 2009. Making the most of what you have: Managerial ability as a source of resource value creation. Strategic Management J. 30(5) 457-485.

Holmström, B. 1979. Moral hazard and observability. Bell J. Econom. 10(1) 74-91.

Holmström, B., P. Milgrom. 1987. Aggregation and linearity in the provision of intertemporal incentives. Econometrica 55 303-328.

Huselid, M. A. 1995. The impact of human resource management practices on turnover, productivity and corporate financial performance. Acad. Management J. 38(3) 635-672.

Ichniowski, C., K. Shaw, G. Prennushi. 1997. The effects of human resource management practices on productivity: A study of steel finishing lines. Amer. Econom. Rev. 87(3) 291-313.

Judson, R. A., A. L. Owen. 1999. Estimating dynamic panel data models: A guide for macroeconomists. Econom. Lett. 65(1) 9-15.

Kanter, R. M. 2004. The middle manager as innovator. Harvard Bus. Rev. (July-August) 150-161.

Kaplan, R. S., D. P. Norton. 1992. The balanced scorecardMeasures that drive performance. Harvard Bus. Rev. (JanuaryFebruary) 71-79.

Lambert, R., D. Larcker, K. Weigelt. 1993. The structure of organizational incentives. Admin. Sci. Quart. 38(2) 438-461.

Lazear, E., S. Rosen. 1981. Rank-order tournaments as optimum labor contracts. J. Political Econom. 89(5) 841-864.

Leepak, D., M. Taylor, A. Tekleab, J. Marrone, D. Cohen. 2007. An examination of the use of high-investment human resource systems for core and support employees. Human Resource Management 46(2) 223-246.

Lieberson, S., J. O'Connor. 1972. Leadership and organizational performance: A study of large corporations. Amer. Sociol. Rev. 37(2) 117-130.

Lieberman, M. B., L. J. Lau, M. D. Williams. 1990. Firm-level productivity and management influence: A comparison of U.S. and Japanese automobile producers. Management Sci. 36(10) 1193-1215.

Lucas, R. E., Jr., 1978. On the size distribution of business firms. Bell J. Econom. 9(2) 508-523.

Macduffie, J. P. 1995. Human resource bundles and manufacturing performance: Organizational logic and flexible production systems in the world auto industry. Indust. Labor Relations Rev. 48(2) 197-221. 
Mundlak, Y. 1961. Empirical production function free of management bias. J. Farm Econom. 43(1) 44-56.

Murphy, K. J. 1986. Incentives, learning, and compensation: A theoretical and empirical investigation of managerial labor contracts. RAND J. Econom. 17(1) 59-76.

Nickell, S. J. 1981. Biases in dynamic models with fixed effects. Econometrica 49(6) 1417-1426.

Pfeffer, J. 1998. The Human Equation: Building Profits By Putting People First. Harvard Business School Press, Boston.
Prendergast, C. 1999. The provision of incentives in firms. J. Econom. Literature 37(1) 7-63.

Roth, K., S. O'Donnell. 1996. Foreign subsidiary compensation strategy: An agency theory perspective. Acad. Management J. 39(3) 678-703.

Terviö, M. 2008. The difference that CEOs make: An assignment model approach. Amer. Econom. Rev. 98(3) 642-668.

Zhou, X. 2000. CEO pay, firm size, and corporate performance: Evidence from Canada. Canadian J. Econom. 33(1) 213-251. 